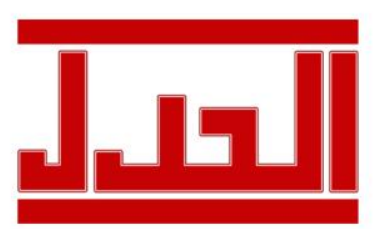

ISSN: $1979-4940$

E-ISSN : 2477-0124
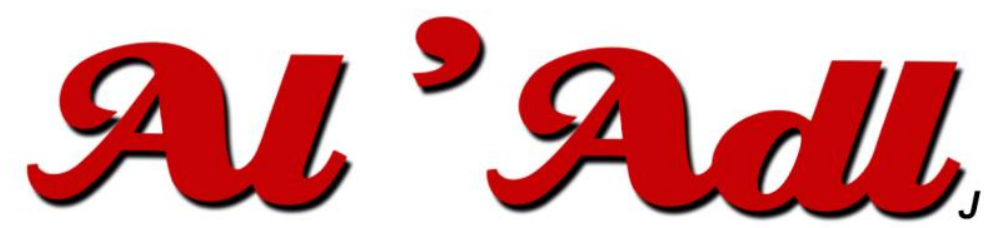

Jurnal Hukum

Editorial Office: Faculty of Law, Islamic University Of Kalimantan,

Jalan Adhyaksa No. 2 Kayutangi Banjarmasin, Kalimantan Selatan, Indonesia (70123)

Email: aladl@uniska-bjm.ac.id

Web: http://ojs.uniska-bjm.ac.id

\title{
ASPEK-ASPEK HUKUM TENTANG PERMOHONAN PERNYATAAN PAILIT
}

\author{
${ }^{[1]}$ Afif Khalid*, ${ }^{[2]}$ Iwan Riswandi, ${ }^{[3]}$ Salamiah \\ Universitas Islam Kalimantan Muhammad Arsyad Al Banjari \\ Jl. Adhyaksa, Kayu Tangi 1 Jalur 2 No.2, Sungai Miai, Kec. Banjarmasin Utara, Kota \\ Banjarmasin, Kalimantan Selatan 70123 \\ Email: ${ }^{[1]}$ afif85fhuniska@ gmail.com* ${ }^{[2]}$ iwanriswandie2@ gmail.com, \\ ${ }^{[3]}$ khairisalamiah140@gmail.com \\ *coressponding author
}

$\begin{array}{ll}\text { Submitted } & : \text { 29 Desember 2021 } \\ \text { Revised } & : \text { 25 Januari } 2022 \\ \text { Accepted } & : \text { 30 Januari } 2022 \\ \text { Published } & : \text { 1 Februari } 2022\end{array}$

\begin{abstract}
Bankruptcy is a legal proceeding carried out to settle the debts of a company that cannot be paid, as stipulated in Law No. 37 of 2004 on Bankruptcy and Suspension of Debt Payment Obligations. The law evidently shows a deficiency, hence a clear and firm arrangement is needed for legal certainty. This research aims to determine the legal status of the bankruptcy statement application, as well as rights restrictions and authority of curators with supervisory judges in the management and enforcement of bankruptcy property. This research used normative legal research - research on primary, secondary, and tertiary legal materials. The legal materials were collected through a literature review. The collected legal materials were processed and analysed qualitatively - processing and analysing without using numbers. The results showed that first, the legal status of the bankruptcy application is a lawsuit case referring to Article 11 and Article 12 of Law No. 37 of 2004, as in the cassation application, it consists of an applicant and a cassation respondent. Second, the rights and authorities of curators and supervisory judges differ in the management and enforcement of bankruptcy property.
\end{abstract}

Keywords: Application; Bankruptcy Statement.

\begin{abstract}
Abstrak
Kepailitan merupakan lembaga hukum yang berfungsi sebagai sarana penyelesaian utang suatu perusahaan yang tidak mampu dibayar. Sebagaimana diatur dalam Undang-Undang Nomor 37 Tahun 2004 tentang Kepailitan dan Penundaan Kewajiban Membayar Utang. Ternyata undang-undang tersebut menunjukkan adanya kekurangan, sehingga diperlukan pengaturan yang jelas dan tegas demi kepastian hukum. Adapun tujuan penelitian ini untuk mengetahui status hukum permohonan pernyataan pailit, serta batasan hak dan kewenangan kurator dengan hakim pengawas dalam pengurusan serta pemberesan harta pailit. Penelitian ini menggunakan jenis penelitian hukum normatif, yaitu penelitian terhadap bahan-bahan hukum primer, sekunder, dan tersier. Bahan hukum tersebut dikumpulkan melalui studi pustaka. Bahan-bahan hukum yang telah terkumpul diolah dan dianalisis secara kualitatif, yaitu pengolahan dan penganalisaan tanpa menggunakan angka-angka. Hasil penelitian menunjukkan, bahwa, Pertama status hukum permohonan pailit merupakan perkara gugatan dengan mengacu pada Pasal 11 serta Pasal 12 Undang-Undang Nomor 37 Tahun 2004, karena dalam permohonan kasasi terdapat pihak pemohon dan termohon kasasi. Kedua, hak dan kewenangan kurator dan hakim pengawas berbeda dalam rangka pengurusan dan pemberesan harta pailit.
\end{abstract}

Kata kunci: Permohonan; Pernyataan Pailit. 


\section{PENDAHULUAN}

Krisis moneter yang melanda hampir seluruh belahan dunia, termasuk negara Indonesia pada pertengahan tahun 1997 telah membuat sendi-sendi perekonomian porakporanda. Dunia bisnis adalah dunia yang paling terpengaruh dan dirasakan oleh krisis ekonomi. Indonesia adalah salah satu negara yang paling terpukul dan terkena dampak terburuk. Oleh karena tidak sedikit dunia usaha yang mengalami kebangkrutan, sedangkan dunia usaha yang masih dapat bertahan, kegiatan usahanya berjalan tersendat-sendat.

Untuk mengantisipasi adanya kecenderungan dunia usaha yang mengalami kebangkrutan sehingga berakibat pada ketidakmampuan dunia usaha memenuhi kewajibankewajiban yang jatuh tempo, maka pemerintah memilih langkah yang cukup signifikan terhadap peraturan perundang-undangan, diantaranya dengan merevisi undang-undang kepailtian yang berlaku selama ini.

Inisiatif pemerintah untuk merevisi undang-undang kepailitan salah satunya timbul karena ada "tekanan" dari pihak Internasional Monetary Fund (IMF) atau Dana Moneter Internasional yang mendesak agar Indonesia telah menyempurnakan perangkat hukum yang mengatur pelaksanaan kewajiban debitur kepada kreditur. IMF berpendapat bahwa peraturan kepailitan yang ditinggalkan oleh pemerintah kolonial Belanda selama ini tidak sempurna dan tidak memenuhi tuntutan zaman. ${ }^{1}$

Desakan IMF tersebut seolah-olah mendikte, Indonesia tidak dapat mengelaknya. Oleh karena negara Indonesia hampir bangkrut akibat krisis ekonomi yang berkepanjangan, IMF bersedia memberikan bantuan (Utang) asalkan mengikuti aturan main yang telah ditetapkannya, yaitu merevisi peraturan hukum kepailitan.

Kehidupan perekonomian nasional yang makin terpuruk, maka dapat dipastikan tidak sedikit dunia usaha yang ambruk, sehingga berdampak pada kelancaran aktivitasnya, termasuk dalam memenuhi kewajibannya kepada kreditur. Keambrukan dunia usaha akan memberikan dampak masalah yang cukup besar apabila aturan main yang tidak memberikan jaminan kepastian hukum. kepailitan bukanlah semata sebuah upaya untuk mempermudah sebuah usaha, baik itu milik perorangan maupun berbentuk korporasi menjadi bangkrut, melainkan kepailitan adalah salah satu upaya untuk mengatasi kebangkrutan sebuah usaha. ${ }^{2}$ Perlu ada aturan main yang dapat digunakan dengan cepat, terbuka dan efektif untuk memberikan kesempatan kepada debitur dan kreditur untuk mencari penyelesaian yang adil.

\footnotetext{
${ }^{1}$ Ahmad Yani dan Gunawan Widjaja. (2002), Seri Hukum Bisnis Kepailitan, Jakarta: PT. Raja Grafindo Persada, hlm. 1.

${ }^{2}$ Ronald Saija (2018). Penyalahgunaan Keadaan dalam Prosedur Permohonan Pailit di Pengadilan Niaga, Jurnal SASI, Volume 24 Nomor 1, hlm. 17.
} 
Salah satu instrumen hukum yang menjadi dasar penyelesaian utang dan piutang serta berkaitan erat dengan kepailitan dalam dunia usaha adalah pengaturan kepailitan, termasuk pengaturan penangguhan kewajiban utang.

Untuk perlu ada peraturan yang dapat digunakan secara cepat, terbuka dan efektif sehingga memberikan kesempatan kepada para pihak dalam hal ini adalah debitur dan kreditur untuk melakukanupaya penyelesaian yang adil. Salah satu dasar hukum yang menjadi penopang bagi penyelesaian utang piutang dan identik dengan kebangkrutan dunia usaha adalah peraturan tentang kepailitan, hal ini pun juga termasuk didalamnya peraturan tentang penundaan kewajiban pembayaran utang.

Pada tahun 1998 peraturan hukum kepailitan tersebut dilakukan perubahan Peraturan Pemerintah Pengganti Undang-Undang Nomor 1 Tahun 1998 tentang Perubahan Atas Undang-Undang tentang Kepailitan. Selanjutnya Peraturan Pemerintah Pengganti UndangUndang tersebut menjadi Undang-Undang yaitu Undang-Undang Nomor 4 Tahun 1998. Ternyata perubahan terhadap perubahan peraturan hukum kepailitan tersebut belum juga sesuai dengan perkembangan dan kebutuhan hukum masyarakat.

Untuk memberikan landasan hukum yang berkepastian hukum dan keadilan, maka keberadaan Undang-Undang Nomor 4 Tahun 1998 diganti dengan Undang-Undang Nomor 37 Tahun 24 tentang Kepailitan dan Penundaan Kewajiban Pembayaran Utang yang diundangkan pada tanggal 18 Oktober 2004. Namun pada kenyataannya, implementasi UU Kepailitan tahun 2004 malah tak semudah yang dibayangkan. "justru lebih berat dari UU Kepailitan tahun 1998. Padahal krisis moneter sudah lewat ,Substansi UU Kepailitan dan PKPU bertentangan dengan hakikat dari hukum kepailitan. ${ }^{3}$

Eksistensi Undang-Undang Nomor 37 Tahun 2004 dalam perkembangannya selama ini oleh para ahli hukum perlu disempurnakan, karena terdapat beberapa ketentuan yang kurang memberikan kepastian hukum. Adapun ketentuan tersebut, antara lain seperti dikatakan oleh mantan Hakim Pengdilan Niaga, Parwoto Wigujosumarto yaitu perlu penegasan status perkara permohonan pernyataan pailit, apakah perkara permohonan (voluntair) ataukah perkara gugatan (contentiosa).

Permasalahan lainnya yang juga perlu adanya kepastian hukum sebagaimana dikemukakan oleh Mantan Ketua AKPI, Ricardo Simanjuntak yaitu adanya ketidakjelasan

\footnotetext{
${ }^{3}$ Mochamad Cahyo Pamungkas, Mahendra Wardhana (2021). Tinjauan Yuridis Tentang Pengaturan Pihak yang Berwenang dalam Mengajukan Permohonan Pailit Bagi Perusahaan Umum, Novum : Jurnal Hukum, Volume 8 Nomor 1, hlm. 2.
} 
batasan hak dan kewenangan kurator dengan hakim pengawas dalam tugas pengurusan dan pemberesan harta pailit. ${ }^{4}$

Berdasarkan persoalan hukum yang terdapat di dalam UU Kepailitan dan Penundaan pembayaran utang sebagaimana dikemukakan oleh Mantan Hakim Pengadilan Niaga dan Mantan Ketua AKPI tersebut di atas, maka penulis tertarik untuk meneliti dan mengkajinya dengan tujuan apakah Undang-Undang Nomor 37 Tahun 2004 tidak jelas mengatur mengenai status permohonan pailit serta hak dn kewenangan kurator dengan hakim pengawas dalam tugas pengurusan dan pemberesan harta pailit.

${ }^{4}$ Sejumlah Persoalan Hukum Mendesak Adanya Revisi UU Kepailitan. https://www.hukumonline.com. (diakses pada 10 Desember 2021) 
ISSN: $1979-4940$

E-ISSN : $2477-0124$
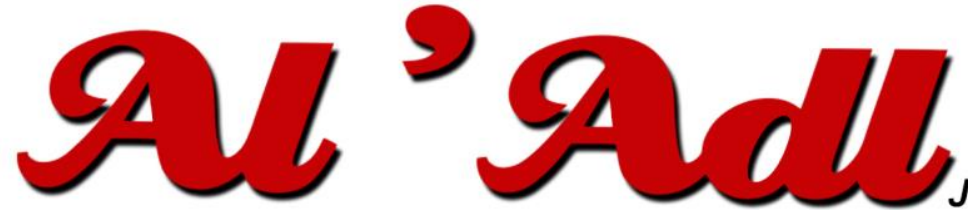

Jurnal Hukum

Editorial Office: Faculty of Law, Islamic University Of Kalimantan,

Jalan Adhyaksa No. 2 Kayutangi Banjarmasin, Kalimantan Selatan, Indonesia (70123)

Email: al_adl@uniska-bjm.ac.id

Web: http://ojs.uniska-bjm.ac.id

\section{RUMUSAN MASALAH}

Bertolak pada latar belakang tersebut, dengan ini permasalahannya dapat dirumuskan sebagai berikut:

1. Bagaimana status hukum permohonan pernyataan pailit?

2. Apa saja batasan hak dan kewenangan kurator dengan hakim pengawas dalam pengurusan dan pemberesan harta pailit?

\section{METODE PENELITIAN}

Dalam pembuatan sebuah karya ilmiah terutama karya ilmiah penelitian hukum diharuskan menggunakan metode penelitian hukum. Ilmu hukum berusaha untuk menampilkan hukum secara integral sesuai dengan kebutuhan kajian ilmu hukum itu sendiri, sehingga metode penelitian dibutuhkan untuk memperoleh arah penelitian yang komprehensif. ${ }^{5}$ Penelitian ini menggunakan jenis penelitian hukum normatif. Menurut Soerjono Soekanto dan Sri Mamuji bahwa penelitian hukum normatif atau penelitian hukum kepustakaan adalah "penelitian hukum yang dilakukan dengan cara meneliti bahan pustaka atau data sekunder". 6 Sedangkan Mukti Fajar ND dan Yulianto Achmad bahwa penelitian hukum normatif adalah "Penelitian hukum yang meletakkan hukum sebagai sistem norma. Sistem norma yang dimaksud adalah mengenai asas-asas, norma, kaidah dari peraturan perundang-undangan, Putusan Pengadilan, Perjanjian serta doktrin (ajaran)". 7

Berdasarkan pegertian di atas, maka yang dimaksud dengan penelitian hukum normatif dalam tulisan ini adalah penelitan terhadap norma hukum yang termuat dalam Undang-Undang Nomor 37 Tahun 2004, terutama mengenai status hukum permohonan pernyataan pailit dan batasan hak dan kewenangan kurator dengan hakim pengawas dalam pengurusan serta pemberesan harta pailit.

\footnotetext{
${ }^{5}$ Yati Nurhayati, "Perdebatan Metode Normatif dengan Metode Empirik Dalam Penelitian Ilmu Hukum Ditinjau Dari Karakter, Fungsi dan Tujuan Ilmu Hukum”, Jurnal Al Adl, Volume 5 Nomor 10, 2013, hlm. 15.

${ }^{6}$ Soerjono Soekanto dan Sri Mamuji. 2010. Peneltiian Hukum Normatif Suatu Tinjauan Singkat. Jakarta: PT. Raja Grafindo Persada, hlm. 14.

${ }^{7}$ Mukti Fajar ND dan Yulianto Achmad. 2010. Dualisme Penelitian Hukum Normatif dan Hukum Empiris. Yogyakarta: Pustaka Pelajar, hlm. 34.
} 
Pendekatan Penelitian ini menggunakan pendekatan perundang-undangan (statute approach) dan pendekatan konsep (conceptual approach). Pendekatan perundang-undangan merupakan pendekatan yang digunakan untuk mengkaji dan menganalisis undang-undang yang berkaitan dengan persoalan hukum yang diteliti. Pendekatan konsep adalah beranjak dari pandangan-pandangan dan doktrin-doktrin yang berkembang di dalam ilmu hukum. Dengan mempelajari pandangan-pandangan dan doktrin-doktrin tersebut akan ditemukan ideide yang melahirkan pengertian-pengertian hukum, konsep-konsep hukum dan asas-asas hukum yang relevan dengan isu yang dibahas.

Sifat penelitian ini bersifat deskriptif analitis, yaitu suatu penelitian yang bertujuan untuk menggambarkan atau menjelaskan gejala hukum, dalam hal ini adalah megenai permasalahan status hukum permohonan pernyataan pailit dan batasan hak dan kewenangan kurator dengan hakim pengawas dalam pengurusan serta pemberesan harta pailit, kemudian dianalisis berdasarkan peraturan hukum yang berlaku. Sedangkan bahan-bahan hukum yang digunakan dalam penelitian ini terdiri dari:

a. Bahan hukum primer, yaitu bahan hukum yang bersifat mengikat yang berupa HIR/RBg tentang peraturan hukum acara perdata, dan Undang-Undang Nomor 37 Tahun 2004 tentang Kepailitan dan Penundaan Kewajiban Pembayaran Utang.

b. Bahan hukum sekunder, yaitu bahan hukum yang berupa buku-buku hukum, jurnal hukum, artikel, dan lain-lain yang relevan dengan pokok bahasan.

c. Bahan hukum tersier, yaitu bahan hukum yang dapat menjelaskan bahan hukum primer dan bahan hukum sekunder yang berupa kamus hukum dan ensiklopedia.

Bahan-bahan hukum dalam penelitian ini dikumpulkan melalui studi pustaka, yaitu penelitian dengan cara meneliti dan menelaah peraturan perundang-undangan dan literatur yang relevan dengan pokok bahasan. Bahan-bahan hukum tersebut kemudian diolah melalui tahapan-tahapan yaitu coding, editing, reconstrukturing, dan sistematizing. Setelah dilakukan pengolahan, maka selanjutnya data tersebut dianalisis secara kualitatif, yaitu analisis data yang tidak menggunakan angka, melainkan memberikan gambaran dengan kata-kata atas temuan-temuan, sehingga lebih mengutamakan kualitas dari data, dan bukan kuantitas.

\section{PEMBAHASAN}

\section{Status Hukum Permohonan Pernyataan Pailit.}

Istilah kepailitan di Indonesia berasal dari kata pailit yang dalam bahasa Belanda yaitu failliet yang berarti kebangkrutan, ${ }^{8}$ dan faillissement untuk istilah kepailitan yang berarti

\footnotetext{
${ }^{8}$ S. Wojowasito. (1985), Kamus Umum Belanda - Indonesia. Jakarta: Ichtiar Baru-Van Hoeve, hlm. 188.
} 
keadaan bangkrut. ${ }^{9}$ Sedangkan dalam bahasa Inggris untuk pailit dan kepailitan digunakan istilah bankrupt dan bankruptcy. ${ }^{10}$

Pengertian kepailitan telah dirumuskan oleh para ahli, antara lain R. Subekti dan R. Tjitrosudibio menyatakan, pailit adalah "keadaan seorang debitur apabila ia telah menghentikan pembayaran utang-utangnya. ${ }^{11}$ Suatu keadaan yang memang dikehendaki adanya campur tangan majelis hakim guna menjamin kepentingan pihak terkait dari para krediturnya. ${ }^{12}$ Kemudian menurut Zaeny Asyhadie, kepailitan adalah "suatu keadaan dimana seorang debitur tidak membayar kreditnya yang telah jatuh waktu dan dapat ditagih". ${ }^{13}$

Pengertian autentik dari kepailitan ditentukan dalam Pasal 1 angka 1 Undang-Undang Nomor 37 Tahun 2004, yaitu "sita umum atas semua kekayaan debitur pailit yang pengurusan dan pemberesannya dilakukan oleh kurator di bawah pengawasan hakim pengawas sebagaimana diatur dalam undang-undang ini”. Berdasarkan pengertian autentik ini dapat dikatakan bahwa pada prinsipnya kepailitan adalah sita umum (beslag) atas kekayaan debitur pailit.

Untuk dapat mengajukan permohonan pernyataan pailit seorang debitur, maka harus memenuhi persyaratan tertentu. Adapun persyaratan pengajuan permohonan pernyataan pailit sebagaimana ditentukan dalam Pasal 2 Ayat (1) Undang-Undang Nomor 37 Tahun 2004, yaitu "Debitur yang mempunyai dua atau lebih kreditur dan tidak membayar lunas sedikitnya satu utang yang telah jatuh waktu dan dapat ditagih, dinyatakan pailit dengan putusan pengadilan, baik atas permohonannya sendiri maupun atas permohonan satu atau lebih krediturnya". Berdasarkan ketentuan tersebut, bahwa syarat untuk mengajukan debitur debitur pailit, yaitu :

a. Debitur mempunyai dua atau lebih kreditur;

b. Debitur tidak membayar sedikitnya satu utang yang telah jatuh tempo dan dapat ditagih.

Akibat hukum bagi debitur setelah dinyatakan pailit adalah bahwa ia tidak boleh lagi mengurus harta kekayaan yang dinyatakan pailit, dan selanjutnya yang akan mengurus harta

\footnotetext{
${ }^{9}$ Ibid.

${ }^{10} \mathrm{https} / / /$ www.thelawdicitionary.org (diakses pada 10 Oktober 2021).

${ }_{11}$ R. Subekti dan R. Tjitrosudibio. (1983), Kamus Hukum. Jakarta: PT. Raja Grafindo Persada, hlm. 225.

${ }^{12}$ Victor Situmorang dan Soekarso. (1999), Pengantar Hukum Kepailitan di Indonesia, Jakarta: Rhineka Cipta, hlm. 18.

${ }^{13}$ Zaeny Asyhadie. (2005), Hukum Bisnis Proses dan Pelaksanaannya di Indonesia, Jakarta: PT. Raja Grafindo Persada, hlm. 225.
} 
kekayaan atau perusahaan debitur pailit tersebut adalah Kurator. Untuk menjaga dan mengawasi perjalanan proses kepailitan (pengurusan dan pembesaran harta pailit). ${ }^{14}$

Dalam hal terjadinya kepailitan perseroan, maka tidak secara a priori direksi bertanggung ja- wab secara pribadi atas perseroan tersebut, namun, sebaliknya bahwa direksi mesti bebas dari tanggung jwab terhadap kepailitan PT. Tanggung jawab di- reksi yang perusahaannya mengalami pailit, pada prinsipny adalah sama dengan tanggung jawab direksi yag perusahaan tidak mengalami pailit. ${ }^{15}$ Menurut Undang-Undang Nomor 37 Tahun 2004 bahwa permohonan pernyataan pailit diajukan kepada Pengadilan Niaga dalam lingkup peradilan umum. Undang-undang tersebut tidak mengatur Pengadilan Niaga pada bab sendiri, akan tetapi masuk pada Bab V tentang ketentuan lain-lain mulai dari Pasal 299 sampai dengan Pasal 303. Begitu pula dalam penyebutannya pada setiap Pasal cukup dengan menyebutkan kata "Pengadilan" tanpa ada kata "Niaga". Pasal 1 angka 7 Undang-Undang Nomor 37 Tahun 2004 menentukan, pengadilan adalah "Pengadilan Niaga dalam lingkungan Peradilan Umum".

Sedangkan dalam hal pembuktiannya, selanjutnya diatur pada ketentuan Pasal 8 ayat (4) UU Nomor 37 Tahun 2004: "Permohonan penyataan pailit harus dikabulkan apabila terdapat fakta atau keadaan yang terbukti secara sederhana bahwa persyaratan untuk dinyatakan pailit sebagaimana yang dimaksud dalam Pasal 2 ayat (1) telah terpenuhi" Yang dimaksud dengan fakta atau keadaan yang terbutki secara sederhana adalah fakta dua atau lebih kreditor dan fakta utang yang telah jatuh tempo dan tidak dibayar. Sedangkan perbedaan jumlah utang yang didalilkan oleh pemohon pailit dan termohon pailit tidak menjadi halangan untuk dinyatakannya pailit. ${ }^{16}$

Para pihak yang terlibat dalam perkara kepailitan, yaitu pemohon pailit dan termohon pailit. Menurut Pasal 2 Undang-Undang Nomor 37 Tahun 2004 bahwa yang dapat menjadi pemohon dalam perkara pailit, antara lain salah satu dari pihak berikut ini: pihak debitur sendiri, salah satu atau lebih kreditur, kejaksaan jika menyangkut kepentingan umum, dan Bank Indonesia apabila debiturnya adalah Bank. Sedangkan pihak termohon pailit adalah debitur yang mempunyai dua atau lebih kreditur dan tidak membayar sedikitnya satu utang yang telah jatuh waktu dan dapat ditagih.

${ }^{14}$ Erni Widjajati. (2017), Tanggung Jawab Direksi Perseroan terbatas yang Dinyatakan Pailit, Jurnal Selisik, Volume 3 Nomor 5, hlm. 24.

15 Agus salim harahap (2008). Tanggung Jawab Direksi dalam Kepailitan Perseroan Terbatas, Lex Jurnalica, Volume 5 Nomor 3, hlm. 166.

${ }^{16}$ Muhammad Redha Anshari (2016). Rekayasa Piutang oleh Kreditor untuk Memenuhi Persyaratan Permohonan Pernyataan Pailit, Lex Renaissance, Volume 1 Nomor 1, hlm. 133. 
Oleh karena Pasal 11 dan Pasal 12 Undang-Undang Nomor 37 Tahun 2004 mendudukkan pemohon dan termohon kasasi sebagai pihak yang berperkara, yang berarti status perkara permohonan pailit adalah perkara gugatan.

Ketentuan Pasal 11 dan Pasal 12 Undang-Undang Nomor 37 Tahun 2004 pada prinsipnya mengatur tentang pengajuan upaya hukum kasasi atas putusan permohonan pernyataan pailit. Berdasarkan kedua ketentuan tersebut, pemohon kasasi wajib menyampaikan memori kasasi, dan termohon kasasi dapat mengajukan kontra memori kasasi kepada panitera pengadilan yang memutus perkaranya apda persidangan tingkat pertama. Dari ketentuan ini, apakah permohonan pernyataan pailit merupakan perkara permohonan ataukah perkara gugatan.

Hukum Acara Perdata sebagaimana diatur dalam HIR/RBg membedakan antara permohonan (voluntair) dan gugatan (contentiosa). Retowulan Sutantio dan Iskandar Oeripkartawinata mengatakan bahwa dalam perkara gugatan terdapat suatu sengketa yang harus diselesaikan dan diputus oleh pengadilan. Sedangkan dalam permohonan tidak ada sengketa, hakim mengeluarkan suatu penetapan atau lazimnya disebut dengan putusan declatoir yaitu putusan yang bersifat menetapkan atau menerangkan saja. ${ }^{17}$

Gugatan contentiosa atau gugatan perdata (gugatan saja) adalah perselisihan perdata yang mengandung permasalahan antara dua pihak atau lebih yang diajukan kepada Ketua Pengadilan Negeri yang mana salah satu penggugat untuk menggugat pihak lain sebagai tergugat. Ciri khas gugatan adalah:

1. Permasalahan hukum yang diajukan ke pengadilan mengandung sengketa;

2. Terjadi sengketa diantara para pihak, minimal dua pihak.

3. Bersifat partai dengan komposisi yang satu bertindak dan berkedudukan sebagai penggugat dan pihak lainnya berkedudukan sebagai tergugat.

4. Tidak boleh dilakukan secara sepihak, hanya pihak penggugat atau tergugat saja.

5. Pemeriksaan sengketa harus dilakukan secara kontradiktor dari permulaan sidang sampai putusan dijatuhkan. ${ }^{18}$

Berdasarkan perbedaan antara permohonan dan gugatan tersebut di atas, maka adanya Pasal 11 dan Pasal 12 Undang-Undang Nomor 37 Tahun 2004 yang menentukan bahwa pemohon kasasi wajib menyampaikan memori kasasi dan termohon kasasi dapat mengajukan

${ }^{17}$ Retnowulan Sutantio dan Iskandar Oeripkartawinata. (1999), Hukum Acara Perdata Dalam Teori dan Praktik. Bandung: Mandar Maju, hlm. 10.

18 Ivan Ari. Perbedaan Prinsip Antara Permohonan dengan Gugatan. http://www.hukumacaraperdata.com (diakses pada 10 November 2021). 
kontra memori kasasi menunjukkan status hukum permohonan pernyataan pailit merupakan perkara gugatan. Oleh karena para pihak kasasi berkedudukan sebagai pihak yang berperkara yang sedang bersengketa. Sebaliknya kalau suatu permohonan tidak mengandung sengketa, sehingga hanya terdapat satu pihak dalam perkara tersebut. Untuk terwujudnya kepastian hukum maka diperlukan pengaturan yang jelas dan tegas tentang status hukum permohonan pernyataan pailit, apakah berupa permohonan atau gugatan. Hal ini penting dilakukan dalam rangka penanganan perkara permohonan pernyataan pailit.

\section{Batasan Hak Dan Kewenangan Kurator Dengan Hakim Pengawas Dalam Pengurusan Dan Pemberesan Harta Pailit.}

Kurator merupakan salah satu pihak yang memegang peranan penting dalam suatu proses perkara pailit. Pasal 1 angka 5 Undang-Undang Nomor 37 Tahun 2004 menyatakan bahwa kurator adalah "Balai Harta peninggalan atau orang perseorangan yang diangkut oleh penngadilan untuk mengurus dan membereskan harta debitur pailit di bawah pengawasan hakim pengawas sesuai dengan undang-undang ini". Dari pengertian ini bahwa kurator dapat berupa Balai Harta Peninggalan atau orang perseorangan yang diangkat oleh pengadilan niaga untuk mengurus dan membereskan harta debitur pailit di bawah hakim pengawas.

Peraturan Menteri Hukum dan Hak Asasi Manusia Nomor M.02-HT.D5.10 Tahun 2005 tentang Permohonan Izin Pelaksanaan Penjualan Harta Kekayaan yang Pemiliknya Dinyatakan Tidak Hadir dan Harta Peninggalan yang Tidak Terurus yang Berada Dalam Pengurusan dan Pengawasan Balai Harta Peninggalan sebagaimana telah diubah dengan Peraturan Menteri Hukum dan Hak Asasi Manusia Nomor 27 Tahun 2013 pada Pasal 1 angka 1 dinyatakan bahwa Balai Harta Peninggalan adalah unit pelaksana teknis pada Kantor Wilayah Departemen Hukum dan Hak Asasi Manusia RI berada di bawah Divisi Pelayanan Hukum dan Hak Asasi Manusia pihak yang secara teknis bertanggung jawab langsung kepada Direktur Jenderal Hukum dan Tata Usaha Negara yang bertugas mewakili dan mengurus kepentingan mereka yang tidak dapat dipaksakan sendiri karena undang-undang atau putusan/putusan pengadilan kepentingannya berdasarkan peraturan perundangundangan.

Dalam Undang-undang Kepailitan masih belum diatur suatu ketentuan yang memberikan ruang gerak kepada Kurator. Sehingga dalam praktek sekarang ini Kurator tidak 
berdaya menghadapi Debitur yang tidak kooperatif. ${ }^{19}$ Pasal 69 Ayat (1) Undang-Undang Nomor 37 Tahun 2004 menentukan, tugas kurator adalah melakukan pengurusan dan/atau pemberesan harta pailit. Dalam melaksanakan tugas tersebut kurator mempunyai wewenang yang merupakan hak, dalam arti kekuasaan yang diberikan oleh undang-undang untuk menjalankan tugasnya. ${ }^{20}$ Pemberian wewenang harus sesuai dengan tugas yang dibebankan. Secara umum sebagaimana ditentukan dalam Pasal 16 Ayat (1) Undang-Undang Nomor 37 Tahun 2004 mempunyai wewenang untuk melaksanakan tugas pengurusan dan/atau pemberesan atas harta pailit sejak tanggal putusan pailit diucapkan meskipun terhadap putusan tersebut diajukan kasasi atau peninjauan kembali.

Berdasarkan ketentuan tersebut di atas, bahwa tugas dan sekaligus wewenang kurator adalah melakukan pengurusan dan/atau pemberesan harta pailit. Oleh karena sejak tanggal putusan pernyataan pailit diucapkan, maka debitur kehilangan hak untuk menguasai dan mengurus harta kekayaannya yang termasuk dalam harta pailit, sehingga kewenangan pengelolaan harta pailit jatuh ke tangan kurator. Dalam Pasal 24 dan Pasal 29 UndangUndang Nomor 37 Tahun 2004, ditentukan bahwa sejak putusan pailit diucapkan semua wewenang debitur untuk menguasai dan mengurus harta pailit termasuk memperoleh keterangan mengenai pembukuan, catatan, rekening bank, dan simpanan debitur dari bank yang bersangkutan beralih kepada kurator. Dengan demikian, tugas utama kurator adalah mengurus dan/atau membereskan harta pailit sejak tanggal putusan pailit diucapkan meskipun terhadap putusan tersebut diajukan kasasi atau peninjauan kembali.

Pasal 15 Ayat (1) Undang-Undang Nomor 37 Tahun 2004 menentukan, bahwa dalam putusan pernyataan pailit, harus diangkat seorang hakim pengawas yang ditunjuk oleh hakim pengadilan niaga. Menurut Pasal 1 angka 8 undang-undang tersebut bahwa hakim pengawas adalah hakim yang ditunjuk oleh pengadilan dalam putusan pailit. Kemudian Pasal 65 Undang-Undang tersebut menentukan bahwa hakim pengawas mengawasi pengurusan dan pemberesan harta pailit. Pengawasan yang dilakukan oleh hakim pengawas mempunyai peranan penting, agar kurator dalam menjalankan tugasnya mengurus dan membereskan harta pailit sesuai dengan aturan dan tidak sewenang-wenang. Adapun bentuk pengawasan yang dapat dilakukan oleh hakim pengawas adalah memberikan penetapan, persetujuan, perizinan, pemberian usul dan kuasa kepada kurator dalam melakukan pengurusan dan pemberesan harta pailit.

\footnotetext{
${ }^{19}$ Freisy Maria Kukus (2015). Perlindungan Hukum Terhadap Profesi Kurator dalam Perkara Kepailitan, Lex Privatum, Volume 3 Nomor 2, hlm. 147-148.

${ }^{20}$ Jono. (2010), Hukum Kepailitan. Jakarta: Sinar Grafika, hlm. 147.
} 
Selain itu, Kurator diberi kewenangan untuk membereskan hak kebendaan Debitor yang telah disita. Dalam pemberesan tersebut, Kurator tidak saja memperhatikan kepentingan Kreditor namun harus memperhatikan kepentingan Debitor pailit. Untuk itu terkait dengan penjualan harta pailit melalui pelelangan, Kurator perlu memperhatikan ketentuan tentang lelang sebagaimana diatur dalam Peraturan Menteri Keuangan Republik Indonesia Nomor 27/PMK.06/2016 Tentang Petunjuk Pelaksanaan Lelang (PMK No. 27 Tahun 2016). ${ }^{21}$

Persoalan yang dikemukakan oleh Mantan Ketua AKPI, Ricardo Simanjuntak, bahwa belum adanya kepastian batasan hak dan kewenangan kurator dengan hakim pengawas dalam tugas pengurusan dan pemberesan harta pailit dalam Undang-Undang Nomor 37 Tahun 2004, sebenarnya telah menunjukkan suatu kepastian hukum. Oleh karena tugas utama kurator dalam kepailitan adalah melakukan pengurusan dan pemberesan harta pailit. Dengan demikian, adanya kejelasan batasan hak dan kewenangan antara kurator dengan hakim pengawas dalam rangka pengurusan dan pemberesan harta pailit. Kurator berkedudukan sebagai pelaksana pengurusan dan pemberesan harta pailit, sementara hakum pengawas berkedudukan selaku pengawas yang melakukan pengawasan terhadap kurator dalam melakukan tugasnya.

\section{PENUTUP}

\section{Kesimpulan}

1. Status hukum permohonan pernyataan pailit adalah perkara gugatan, dan hal ini didasarkan pada Pasal 11 dan Pasal 12 Undang-Undang Nomor 37 Tahun 2004 yang memposisikan pemohon dan termohon kasasi sebagai pihak berperkara. Untuk terwujudnya kepastian hukum, maka status hukum permohonan pernyataan pailit perlu diatur secara tegas dan jelas. Hal ini penting dilakukan karena menyangkut hak dan kepentingan para pihak dalam perkara kepailitan.

2. Undang-Undang Nomor 37 Tahun 2004 telah menentukan batasan yang jelas mengenai hak dan kewenangan kurator dengan hakim pengawas dalam pengawasan dan pemberesan harta pailit. Kurator berhak dan berwenang melakukan pengurusan dan pemberesan harta pailit. Sedangkan hakim pengawas berhak dan berwenang mengawasi kurator dalam pengurusan dan membereskan harta pailit. Untuk kelancaran pengurusan dan pemberesan harta pailit, maka diperlukan koordinasi yang proporsional dan efektif.

${ }^{21}$ Sentosa Sembiring (2017). Eksistensi Kurator dalam Pranata Hukum Kepailitan, Adhaper: Jurnal Hukum Acara Perdata, Volume 3 Nomor 1, hlm. 99. 


\section{DAFTAR PUSTAKA}

\section{Buku}

Asyhadie, Zaeny. (2005), Hukum Bisnis Proses dan Pelaksanaannya di Indonesia. Jakarta: PT. Raja Grafindo Persada.

Fajar ND, Mukti dan Yulianto Achmad. (2010), Dualisme Penelitian Hukum Normatif dan Hukum Empiris. Yogyakarta: Pustaka Pelajar.

Jono. (2010), Hukum Kepailitan. Jakarta: Sinar Grafika.

Subekti, R. dan R. Tjitrosudibio. (1983), Kamus Hukum. Jakarta: PT. Raja Grafindo Persada.

Situmorang, Victor dan Soekarso. (1999), Pengantar Hukum Kepailitan di Indonesia. Jakarta: Rhineka Cipta.

Soekanto, Soerjono dan Sri Mamuji. (2010), Peneltiian Hukum Normatif Suatu Tinjauan Singkat. Jakarta: PT. Raja Grafindo Persada.

Sutantio, Retnowulan dan Iskandar Oeripkartawinata. (1999), Hukum Acara Perdata Dalam Teori dan Praktik. Bandung: Mandar Maju.

Wojowasito, S. (1985), Kamus Umum Belanda - Indonesia. Jakarta: Ichtiar Baru-Van Hoeve. Yani, Ahmad dan Gunawan Widjaja. (2002), Seri Hukum Bisnis Kepailitan. Jakarta: PT. Raja Grafindo Persada.

\section{Peraturan Perundang-Undangan}

Undang-Undang Nomor 37 Tahun 2004 tentang Kepailitan dan Penundaan Kewajiban Pembayaran Utang.

\section{Jurnal}

Agus salim harahap (2008). "Tanggung Jawab Direksi dalam Kepailitan Perseroan Terbatas", Lex Jurnalica, Volume 5 Nomor 3.

Erni Widjajati (2017). “Tanggung Jawab Direksi Perseroan terbatas yang Dinyatakan Pailit", Jurnal Selisik, Volume 3 Nomor 5.

Freisy Maria Kukus (2015) "Perlindungan Hukum Terhadap Profesi Kurator dalam Perkara Kepailitan", Lex Privatum, Volume 3 Nomor 2.

Mochammad Cahyo Pamungkas, Mahendra Wardhana (2021). "Tinjauan Yuridis Tentang Pengaturan Pihak yang Berwenang dalam Mengajukan Permohonan Pailit Bagi Perusahaan Umum”, Novum: Jurnal Hukum, Volume 8 Nomor 1.

Muhammad Redha Anshari (2016). "Rekayasa Piutang oleh Kreditor untuk Memenuhi Persyaratan Permohonan Pernyataan Pailit", Lex Renaissance, Volume 1 Nomor 1. 
Ronald Saija (2018). "Penyalahgunaan Keadaan dalam Prosedur Permohonan Pailit di Pengadilan Niaga", Jurnal SASI, Volume 24 Nomor 1.

Sentosa Sembiring (2017). "Eksistensi Kurator dalam Pranata Hukum Kepailitan", Adhaper: Jurnal Hukum Acara Perdata, Volume 3 Nomor 1.

Yati Nurhayati (2013). "Perdebatan Metode Normatif dengan Metode Empirik Dalam Penelitian Ilmu Hukum Ditinjau Dari Karakter, Fungsi dan Tujuan Ilmu Hukum”, Jurnal Al Adl, Volume 5 Nomor 10.

\section{Internet}

Ivan Ari. Perbedaan Prinsip Antara Permohonan dengan Gugatan. http://www.hukumacaraperdata.com.

Sejumlah Persoalan Hukum Mendesak Adanya Revisi UU Kepailitan. https://www.hukumonline.com.

https://www.thelawdicitionary.org 